\title{
DEFICIT WATERING REDUCES PLANT GROWTH TO A SMALLER EXTENT WITH ARBUSCULAR MYCORRHIZAL ASSOCIATION THAN WITHOUT IT FOR NON-INVASIVE GRASS SPECIES BUT NOT FOR INVASIVE GRASS SPECIES
}

\author{
ENDRESZ, G. ${ }^{1,2} *$ - MOJZES, A. ${ }^{1}-$ KALAPOS, ${ }^{1}{ }^{1}$ \\ ${ }^{I}$ Department of Plant Systematics, Ecology and Theoretical Biology, \\ Institute of Biology, Eötvös Loránd University \\ H-1117 Budapest, Pázmány Péter stny 1C, Hungary \\ (phone: +36-1-381-2188; fax: +36-1-381-2187) \\ ${ }^{2}$ Szent László Secondary School \\ H-1102 Budapest, Körösi Csoma Sándor út 28-34, Hungary \\ (phone: +36-1-262-3599; fax: +36-1-260-2264) \\ *Corresponding author \\ e-mail: endreszgabor@gmail.com
}

(Received 14 ${ }^{\text {th }}$ Dec 2014; accepted $8^{\text {th }}$ Jan 2015)

\begin{abstract}
Symbiotic associations with the soil microbiota, particularly with arbuscular mycorrhizal fungi (AMF), might ameliorate the effects of environmental stress on plants, and this capacity may be different for resident and alien species. In a growth room pot experiment we tested if imposed water deficit leads to greater growth reduction in the absence of AMF than in the presence of AMF for two non-invasive resident (Danthonia alpina, Chrysopogon gryllus) and two invasive (Calamagrostis epigejos, Cynodon dactylon) grass species from semiarid temperate grasslands in Hungary. Both deficit watering and soil sterilization decreased biomass accumulation, but the non-invasive Danthonia and Chrysopogon performed better when grown in intact soil containing AMF than in sterilized soil. In contrast, the invasive Calamagrostis and Cynodon displayed mostly no difference in growth and biomass accumulation between intact and sterilized soil when subjected to water deficit. When plants were grown well-watered but deprived of AMF symbionts, both Danthonia and Chrysopogon achieved poorer growth than in AMF containing soil, while neither Calamagrostis nor Cynodon displayed any reduction. These results indicate that the influence of deficit watering was ameliorated by the presence of AMF in the soil for the resident non-invasive species, while not for the invasive species.
\end{abstract}

Keywords: Calamagrostis epigejos, Chrysopogon gryllus, Cynodon dactylon, Danthonia alpina, grasses

\section{Introduction}

Plant invasions are among the most serious threats to biodiversity worldwide (Lövei, 1997; Vitousek et al., 1997; Mack et al., 2000). There is a wide range of mechanisms through which invasive plants succeed to mass appearance in alien ecosystems (see Hierro et al., 2005 for review). Among others, these include interactions of the invasive plant with the resident soil microbiota (Kourtev et al., 2002; Lorenzo et al., 2010; Bozzolo and Lipson, 2013), particularly with arbuscular mycorrhizal fungi (AMF, Pringle et al., 2009). Invasive plants are often non-mycorrhizal, facultative mycorrhizal (forming association with AMF or not, depending on the environment) or establish association with widely distributed generalist AMF taxa, thus their spread is not restricted by the need of parallel dispersal of specific symbiotic fungi (Richardson et al., 2000; Pringle et al., 2009; Moora et al., 2011; Steinlein, 2013). For non-mycorrhizal or facultative mycorrhizal invasives, plant assimilates saved on mycorrhizal symbiosis can 
be invested into an increased competitive ability (Richardson et al., 2000). The sheer abundance of the alien plant in the new habitat has the capacity to modify the soil AMF community as the alien plant establishes symbiosis with different AMF taxa than resident plants do (Mummey and Rillig, 2006; Niu et al., 2007; Vogelsang and Bever, 2009; Zhang et al., 2010). By a rapid growth and flowering earlier than resident species, invasive plants may preempt the soil AMF community and shape its composition to their own benefit (Wilson et al., 2012). The invasive species can even directly interfere with the local AMF community via releasing inhibitor allelochemicals (Stinson et al., 2006; Hale et al., 2011). In other instances, the alien utilizes the local AMF community to divert assimilates from its neighbors (Reinhart and Callaway, 2006). The limited reliance of invasive plants on AMF is also reflected by the fact that the success of numerous invasive plants is associated with some sort of soil disturbance, which severely harm the soil microbial community itself (Richardson et al., 2000; Steinlein, 2013). In habitats where the soil AMF community is inherently poor (e.g. in early phases of primary succession) invasive species are typically members of nonmycorrhizal plant families (e.g. Amaranthaceae, Brassicaceae; Goodwin, 1992; Richardson et al., 2000).

Arbuscular mycorrhizal fungi (AMF) form symbiosis with the overwhelming majority of terrestrial plants (Wang and Qiu, 2006). Its numerous benefits to the plant include improved mineral (particularly P) nutrition, better water supply and protection against certain root pathogenic fungi (Brundrett, 1991; Newsham et al., 1995; Hu et al., 2014). The AMF symbiosis has been shown to alleviate the effects of various abiotic stresses such as salt stress (Evelin et al., 2009), heavy metals (Hildebrandt et al., 2007), soil compaction (Miransari et al., 2008), and especially water shortage (Al-Karaki et al., 2004; Kristek et al., 2005; Wu and Xia, 2006; Doubková et al., 2013). The mechanisms of AMF induced water stress amelioration include a more efficient exploration of the soil through modification of root morphology (i.e. thinner, longer, more frequently branching roots), improvement and stabilization of soil aggregate structure resulting in higher water holding capacity, enhancement of the accumulation of osmotically active substances in roots, better protection against photodamage through higher amount of plant antioxidants, and enhancement of plant water uptake via stimulation of plant metabolic activity (Augé, 2001; Rapparini and Peñuelas, 2014). For example, Doubková et al. (2013) measured better plant water status and growth in AMF associated than in non-mycorrhizal Knautia arvenis plants when subjected to water stress, and detected a stress severity threshold beyond which the AMF alleviation of water stress failed. In a pot experiment, Zhu et al. (2012) observed higher water content, stomatal conductance, photosynthetic rate and photochemical efficiency for mycorrhizal then for non-mychorrizal maize plants. In a meta-analysis of 54 studies, Jayne and Quigley (2013) quantitatively affirmed that under water deficit conditions mycorrhizal plants achieve greater growth and yield than non-mycorrhizal plants, and in this respect perennials respond more strongly than annuals, and woody plants benefit more than herbaceous plants.

Based on these properties of AMF and invasive plants, we assumed that for noninvasive resident species the presence of the local AMF community in the soil can ameliorate the unfavorable effects of water shortage on plant performance through symbiotic interaction. For invasive species, however, AMF will not make any substantial difference in response to water deficit. To test this hypothesis we grew two invasive and two non-invasive perennial grass (Poaceae) species in a growth room in 
intact or in sterilized field soil, and recorded their photosynthetic and growth responses to deficit watering. We chose grass species for this study because they are dominant components of grasslands, are strongly associated with AMF and include a number of invasive species (Holm et al., 1977; Wang and Qiu, 2006).

\section{Material and Methods}

\section{Species studied}

Four perennial grass (Poaceae) species representing two categories of invasiveness were selected; natural species characteristic in undisturbed vegetation, and aggressive colonist species overwhelming the community upon disturbance (hereafter referred to as invasive species). One $\mathrm{C}_{3}$ species and one $\mathrm{C}_{4}$ species were included in each group to represent the two major photosynthetic pathway types. In a meta-analysis, $\mathrm{C}_{4}$ grasses were found to be more responsive to mycorrhizal inoculation than $\mathrm{C}_{3}$ grasses (Hoeksema et al., 2010). Danthonia alpina Vest is a natural (sub)dominant $\mathrm{C}_{3}$ grass in species-rich xero-mesic grasslands and forest steppe meadows (Illyés and Bölöni, 2007). The $\mathrm{C}_{4}$ tall bunchgrass Chrysopogon gryllus (L.) Trin. is a natural component of xerothermic grasslands, often at the driest microsites (Fekete et al., 1998, 2000). Calamagrostis epigejos (L.) Roth is a rhizomatous tall $\mathrm{C}_{3}$ grass, an aggressive weed which often appears abundantly and halts succession on forest clearings, abandoned agricultural land and in semiarid grasslands (Rebele and Lehmann, 2001; Mihály and Demeter, 2003; Illyés and Bölöni, 2007; Somodi et al., 2008; Házi et al., 2011). The $\mathrm{C}_{4}$ plant Cynodon dactylon (L.) Pers originates from North Africa, but is distributed worldwide today and is considered the second most noxious weed in the world (Holm et al., 1977). It is a presumed archaeophyte in Hungary (Terpó et al., 1999) and usually reaches dominance in warm, open, strongly disturbed habitats (Zólyomi and Fekete, 1994; Török et al., 2008). These latter two grasses were considered as invasive species in this study due to their insignificant presence in undisturbed natural vegetation and aggressive expansion upon disturbance, although Calamagrostis epigejos is native to Hungary, and Cynodon dactylon has long been part of the flora to be considered as naturalized. Biological invasion phenomena, however, are not restricted to alien species as native species may also overwhelm new habitats (i.e. native invasive species, Valéry et al., 2008, 2009). Hereafter species will be shortly referred to by their genus name. AMF symbiosis have been reported for Calamagrostis (Rebele and Lehmann, 2001; Rydlová and Vosátka, 2001; Kovács and Szigetvári, 2002), Cynodon (Kovács and Szigetvári, 2002; Lingfei et al., 2005) and Chrysopogon (Endresz et al., 2013).

\section{Growth conditions and experimental treatments}

Seeds of each species were collected in the same seminatural semiarid grassland at Tard (NE Hungary) between June and September 2007 and stored in paper bags at room temperature until the experiment started in February 2008. Seeds were surface sterilized in $5 \%$ sodium hypochlorite $(\mathrm{NaOCl})$ for $10 \mathrm{~min}$, rinsed with deionized water and germinated on sterilized sand in petri dishes under laboratory conditions. To enhance germination, dry seeds were first incubated at $5{ }^{\circ} \mathrm{C}$ (for one and two weeks for $\mathrm{C}_{4}$ and $\mathrm{C}_{3}$ species, respectively), then warm stratified at $30 / 20{ }^{\circ} \mathrm{C}$ day/night temperature for a week. Pots (of 1.51 volume) were filled with the same amount of a 1:1 mixture of perlite and sieved soil collected in the plant's original habitat. (Perlite was added to the 
soil to provide good soil aeration, water regime and a more even distribution of nutrients added in pulses.) Five seedlings of the same species were planted in each pot and thinned to one plant per pot at 35-42 days after planting (DAP). Plants were grown in a growth room receiving natural light augmented by a $1000-\mathrm{W}$ artificial halogen light source over a daily photoperiod of $12 \mathrm{~h}$. Mean Photosynthetic Photon Flux Density (PPFD) measured right above the grass foliage varied between 440 and $810 \mu \mathrm{mol}$ photon $\mathrm{m}^{-2} \mathrm{~s}^{-1}$ in summer, and between 150 and $440 \mu \mathrm{mol}$ photon $\mathrm{m}^{-2} \mathrm{~s}^{-1}$ in spring on clear days. Pots were rotated every 2 weeks to minimize the effects of possible heterogeneous light distribution on the bench. Air temperature and humidity was measured hourly by using an HOBO Pro RH/Temp device (Onset Computers Inc., Bourne, MA, USA). Mean air temperature was $23.0 \pm 4.0^{\circ} \mathrm{C}$, relative air humidity varied between 33 and 58\% during the day. Plants were watered regularly (every third day), and supplied with mineral nutrients $\left(0.5 \mathrm{ml}\right.$ per pot, $13 \% \mathrm{~N}, 4.5 \% \mathrm{P}_{2} \mathrm{O}_{5}, 6.5 \% \mathrm{~K}_{2} \mathrm{O}$ plus micronutrients (percentage in the $0.5 \mathrm{ml}$ solution), Vitaflora, Hungary) at 3-week intervals.

A factorial experiment was set up to test the effects of AMF and water shortage on photosynthesis and growth of the plants differing in invasiveness. For the AMF treatment, half of the pots were filled with sieved field soil (thus containing the original soil microbiota, including AMF), while the other half contained sterilized sieved field soil (treatment denoted hereafter as sterile soil). Soils were sterilized (heat pasteurized) through several consecutive cycles of heating in a forced ventilation oven at $80{ }^{\circ} \mathrm{C}$ for six hours and subsequent moist incubation at room temperature for one day. With this procedure we aimed at depleting the AMF spore bank in the soil. To examine the influence of water shortage, half of the pots received adequate water to keep their soil continuously wet, while the other half was watered with the same frequency but by adding only one third of the amount of water given to the control each time (deficit watering treatment, started at 42-45 DAP). With this reduced water supply our purpose was to impose a moderate water stress on plants and thus allow the expression of both plant and AMF stress responses. A drastic drought treatment of complete withholding of water from the plants might have resulted in the early death of plants. The two factors with two levels each resulted in four treatments (control (well watered with AMF containing soil), deficit watering; sterile soil and deficit watering+sterile soil). For each species, control and sterile soil treatment contained four independent replicates (pots, $\mathrm{n}=4$ ), while deficit watering and deficit watering + sterile soil treatments were replicated five times $(\mathrm{n}=5)$.

\section{Plant biomass and physiological measurements}

Aboveground parts were harvested at 132-140 DAP and were separated into leaves and stems. Roots were carefully washed from the soil with water. Leaves, stems and roots were dried to constant weight in an oven at $75{ }^{\circ} \mathrm{C}$ and their dry weight was measured (LW, SW and RW, respectively). Before drying, for a subsample of leaves, leaf area (one sided surface area) was measured by using a LI-COR LI-3000A leaf area meter (LI-COR Inc., Lincoln, Nebraska, USA) to a $0.1 \mathrm{~cm}^{2}$ accuracy, and specific leaf area (SLA, area of unit leaf dry weight) was determined. Using SLA obtained in this way, total leaf area per plant (LA) was calculated from the plant's leaf dry weight (LW). From these data, the following variables were calculated: root weight ratio (RWR, root dry weight per unit plant dry weight), stem weight ratio (StWR, stem dry weight per unit plant dry weight), leaf weight ratio (LWR, leaf dry weight per unit plant dry 
weight), and leaf area ratio (LAR, leaf area per unit plant dry weight). To determine initial plant weight and leaf area for growth analysis, 4 (well watered treatments) or 5 (deficit watering treatments) plants per species and AMF treatment were harvested at 41-44 DAP (right before the water deficit treatment started) and LW, SW, RW and LA were measured. For each variable, the average of the 4-5 replicates were used as initial value in subsequent calculation of relative growth rate (RGR).

To assess the plants' photosynthetic activity, we measured instantaneous leaf gas exchange and chlorophyll-a fluorescence at 103-107 DAP on four (well-watered) or five (deficit watering) replicates $(\mathrm{n}=4$ or 5). The leaf was incubated under $1000 \mu$ mol photon $\mathrm{m}^{-2} \mathrm{~s}^{-1}$ (i.e. saturating) actinic white light and as readings became steady net photosynthetic rate $\left(\mathrm{P}_{\mathrm{n}}\right)$ and stomatal conductance for water vapor $\left(\mathrm{g}_{\mathrm{s}}\right)$ were recorded. The $\mathrm{P}_{\mathrm{n}} / \mathrm{g}_{\mathrm{s}}$ ratio was used as a measure of instantaneous photosynthetic water use efficiency (PWUE). These leaf gas exchange variables were calculated based on von Caemmerer and Farquhar (1981), and the steady state values were obtained as the mean of the last 20 consecutive data points $(10 \mathrm{~min})$ of the measurements (following the procedure used by Horton and Neufeld (1998) to obtain $\mathrm{P}_{\mathrm{n} \text { max }}$ ). An ADC LCA-4 open system infrared gas analyzer with PLC4-B leaf chamber (Analytical Development Co., BioScientific Ltd., Hoddesdon, UK) was used for the measurements. Chlorophyll-a fluorescence was measured on the same leaf immediately after leaf gas exchange measurement. The leaf was allowed to incubate to an $1000 \mu \mathrm{mol}$ photon $\mathrm{m}^{-2} \mathrm{~s}^{-1}$ actinic white light and the light-incubated chlorophyll fluorescence parameters were determined such as PSII actual photochemical efficiency (ФPSII), PSII antenna efficiency $\left(\mathrm{F}_{\mathrm{v}}{ }^{\prime} / \mathrm{F}_{\mathrm{m}}{ }^{\prime}\right)$, photochemical quenching $(\mathrm{qP})$ and non-photochemical quenching (NPQ) following Maxwell and Johnson (2000). Then the leaf was dark incubated for at least $15 \mathrm{~min}$ and the dark-incubated fluorescence parameters $\left(\mathrm{F}_{0}, \mathrm{~F}_{\mathrm{m}}, \mathrm{F}_{\mathrm{v}}\right)$ were measured and the maximum photochemical efficiency of PSII $\left(\mathrm{F}_{\mathrm{v}} / \mathrm{F}_{\mathrm{m}}\right)$ was calculated. A Hansatech FMS2 Fluorescence Monitoring System (Hansatech Instruments Ltd., Norfolk, England) were used for these measurements.

Leaf relative water content (RWC) was measured on $5 \mathrm{~cm}$ long leaf segments taken from the middle of the blade. After cutting, fresh weight (FW) was measured, then the leaf segment was allowed to saturate with water in a closed chamber with the basal cut end immersed in tap water for 24 hours, after which the saturated weight (SW) was determined. Finally, leaves were dried to constant weight at $70{ }^{\circ} \mathrm{C}$ and their dry weight (DW) was measured. Relative water content was calculated as ((FW-DW)/(SWDW) $) * 100(\%)$.

\section{Assessment of mycorrhizal colonization}

At the end of the experiment (132-140 DAP) when roots were washed out from the soil, a small subsample was taken from the roots of each plant to determine the degree of AMF colonization. Samples were stored in $50 \%$ ethanol at $5{ }^{\circ} \mathrm{C}$ until examination. Roots were cleaned in $10 \% \mathrm{KOH}$, and stained with aniline blue according to the protocol of Grace and Stribley (1991). From each specimen 30 root segments (of 1-2 cm length) were examined and mycorrhizal structures (hyphae, arbuscules, vesicles) were determined in stained roots according to the method of Trouvelot et al. (1986). The following variables were used to assess the magnitude of AM colonization: frequency of root segments (approx. 1-2 cm) in the root system of a single plant where AMF was found $(\mathrm{F} \%)$, intensity of AMF colonization (estimated percentage of AMF in each root segment, M\%), percentage arbuscule occurrence of the AMF colonized root section 
(a\%), percentage arbuscule occurrence in the whole root $(\mathrm{A} \%)$, percentage vesicle occurrence of the AMF colonized root section $(\mathrm{v} \%)$, percentage vesicle occurrence of the whole root $(\mathrm{V} \%)$.

\section{Statistical analyses}

For each measure of plant performance, two-way ANOVA with water supply and soil sterilization as fixed main effects were used. Means were compared by using the Sidak post hoc test. Two sample t-tests - with Welch's correction if sample variances differed - were used for the comparison of mycorrhizal colonization of roots in wellwatered versus deficit irrigation treated field soil. The significance level was set to $\mathrm{p}<0.05$. For each test, the Graphpad Prism v.6.01 package (Graphpad Software, La Jolla, CA) was used.

\section{Results}

\section{Mycorrhizal colonization of roots}

Soil sterilization was effective for each species as no mycorrhizal structures (hyphae, arbuscules or vesicles) were observed in the roots of plants growing in sterilized soil (data not shown). Plants reared in intact (non-sterilized) field soil were all colonized by AMF with frequency of roots having AMF (F\%) ranging between $47 \%$ and $91 \%$ (Table 1). Arbuscules were common in roots, while vesicles were extremely rare. Compared to well-watered control, deficit watering had no influence on AMF colonization of roots except for Chrysopogon where intensity of colonization (M\%) and percentage arbuscule occurrence in the whole root (A\%) were more than twice as high under deficit watering than in the control (Table 1).

Table 1. Measures of mycorrhizal colonization of roots grown in intact (non-sterilized) field soil in deficit watering treatment $(D)$ and in well-watered control $(C)$. For each trait and species, different letters in superscript indicate significant difference between deficit watering treatment and control. a\% - percentage arbuscule occurrence of the AMF colonized root section; A\%: - percentage arbuscule occurrence in the whole root; F\%frequency of root segments with AMF colonization; M\% - intensity of AMF colonization; v\% - percentage vesicle occurrence of the AMF colonized root section; V\%-percentage vesicle occurrence of the whole root.

\begin{tabular}{lcccccccc}
\hline & \multicolumn{3}{c}{ Non-invasive species } & \multicolumn{3}{c}{ Invasive species } \\
Watering & C & D & C & D & C & D & C & D \\
\hline F\% & $86.7^{\mathrm{a}}$ & $76.7^{\mathrm{a}}$ & $81.7^{\mathrm{a}}$ & $91.3^{\mathrm{a}}$ & $75.8^{\mathrm{a}}$ & $75.3^{\mathrm{a}}$ & $60.0^{\mathrm{a}}$ & $46.7^{\mathrm{a}}$ \\
$\mathrm{M} \%$ & $43.6^{\mathrm{a}}$ & $37.1^{\mathrm{a}}$ & $23.0^{\mathrm{a}}$ & $49.9^{\mathrm{b}}$ & $25.4^{\mathrm{a}}$ & $24.0^{\mathrm{a}}$ & $12.3^{\mathrm{a}}$ & $9.2^{\mathrm{a}}$ \\
$\mathrm{a} \%$ & $83.3^{\mathrm{a}}$ & $85.8^{\mathrm{a}}$ & $56.1^{\mathrm{a}}$ & $70.5^{\mathrm{a}}$ & $65.5^{\mathrm{a}}$ & $62.8^{\mathrm{a}}$ & $46.1^{\mathrm{a}}$ & $56.0^{\mathrm{a}}$ \\
$\mathrm{A} \%$ & $37.4^{\mathrm{a}}$ & $32.7^{\mathrm{a}}$ & $12.8^{\mathrm{a}}$ & $35.7^{\mathrm{b}}$ & $19.2^{\mathrm{a}}$ & $17.4^{\mathrm{a}}$ & $7.4^{\mathrm{a}}$ & $5.9^{\mathrm{a}}$ \\
$\mathrm{v} \%$ & $0.7^{\mathrm{a}}$ & $0.0^{\mathrm{a}}$ & $1.7^{\mathrm{a}}$ & $6.3^{\mathrm{a}}$ & $0.2^{\mathrm{a}}$ & $0.6^{\mathrm{a}}$ & $1.8^{\mathrm{a}}$ & $0.2^{\mathrm{a}}$ \\
$\mathrm{V} \%$ & $0.3^{\mathrm{a}}$ & $0.0^{\mathrm{a}}$ & $0.5^{\mathrm{a}}$ & $3.1^{\mathrm{a}}$ & $0.1^{\mathrm{a}}$ & $0.1^{\mathrm{a}}$ & $0.1^{\mathrm{a}}$ & $0.0^{\mathrm{a}}$ \\
\hline
\end{tabular}




\section{Plant biomass and growth}

Both deficit watering and soil sterilization treatment alone, as well as their combination decreased biomass accumulation, but the two species groups and the individual species did not respond uniformly to these (Tables 2 and 3). For non-invasive species, the reduction of leaf, stem, shoot (leaf + stem) and total plant masses in response to soil sterilization was similar (Danthonia) or even greater (Chrysopogon) than in response to the imposed water shortage (between $30 \%$ and $77 \%$, Figure 1). Root weight declined with deficit watering for Danthonia, while for Chrysopogon it decreased in response to soil sterilization. When water shortage was imposed on plants growing in sterilized soil their biomass was reduced to 27-33\% of that achieved under deficit watering in original field soil (except for root and total plant weight of Danthonia, Figure 1). The response of the invasive grasses was different. Plant biomass and its components decreased in response to deficit irrigation alone, while soil sterilization alone either did not change biomass compared to control (Calamagrostis) or even increased it (root and plant weight for Cynodon, Figure 1). In the combined treatment - when plants were subjected to deficit watering in sterilized soil - biomass accumulation was not smaller (for root weight of Cynodon it was even greater) than that achieved in response to deficit watering treatment in intact field soil (Figure 1). Compared to control, relative growth rate (RGR) was reduced with water deficit, sterile soil, and combined water deficit + sterile soil treatments at an increasing extent in this order for the non-invasive Danthonia and Chrysopogon (Table 3). For the invasive species, sterile soil alone did not decrease RGR, while the reduction brought about by water shortage was not greater for plants grown in sterile than in intact soil (Table 3).

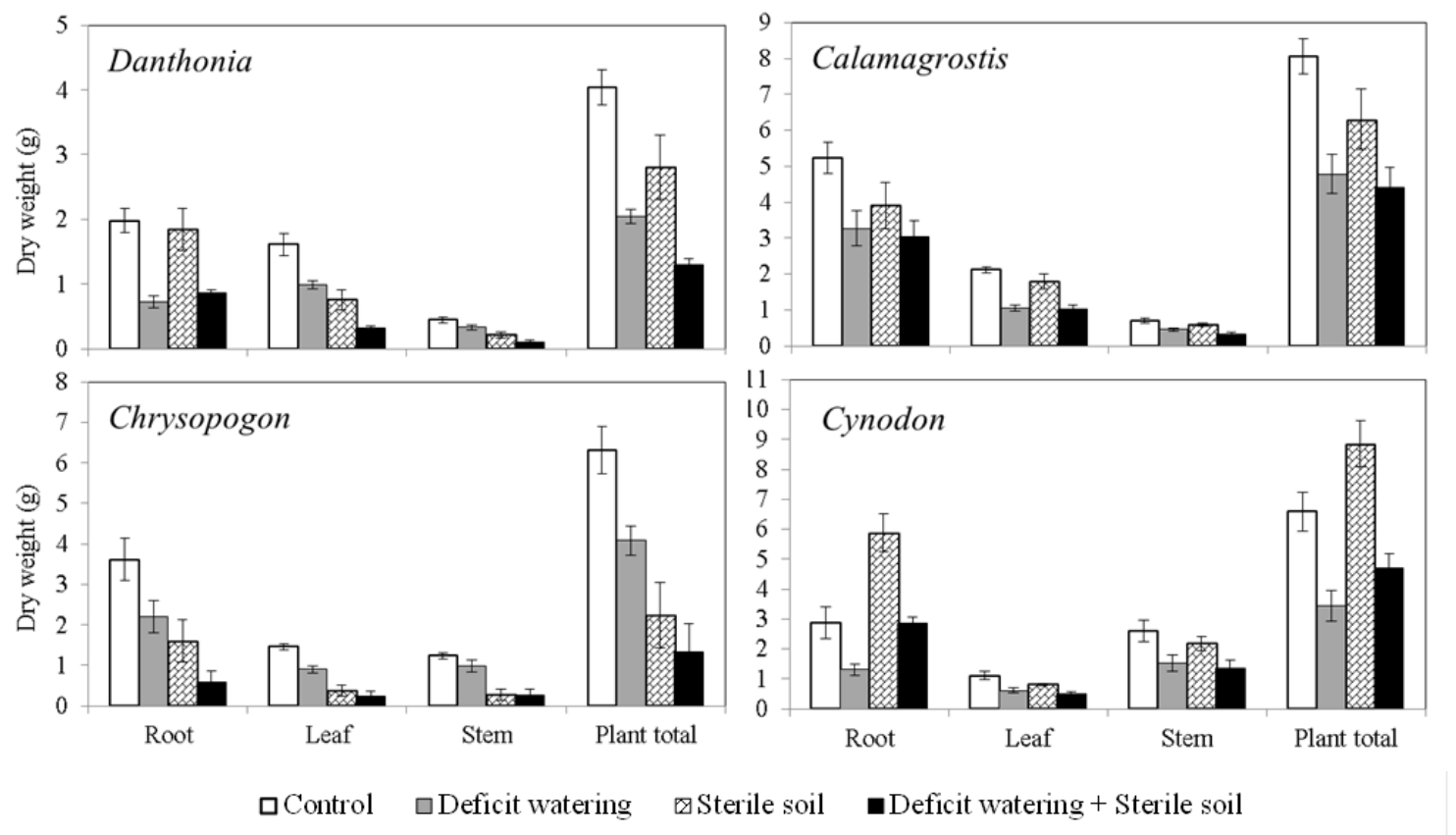

Figure 1. Root, stem, leaf and total plant biomass values for plants subjected to water deficit and/or soil sterilization treatments. Mean values \pm 1 SE. 
Table 2. Results of two-way ANOVA of plant biomass and growth data. Effects are deficit watering $(D)$, soil sterilization $(S)$ and their interaction $(D x S)$. Significant $(p<0.05)$ effects are in bold typeface. Abbreviations: RWR - root weight ratio, SWR - shoot weight ratio, StWR - stem weight ratio, $L W R$ - leaf weight ratio, LAR - leaf area ratio, RGR - relative growth rate.

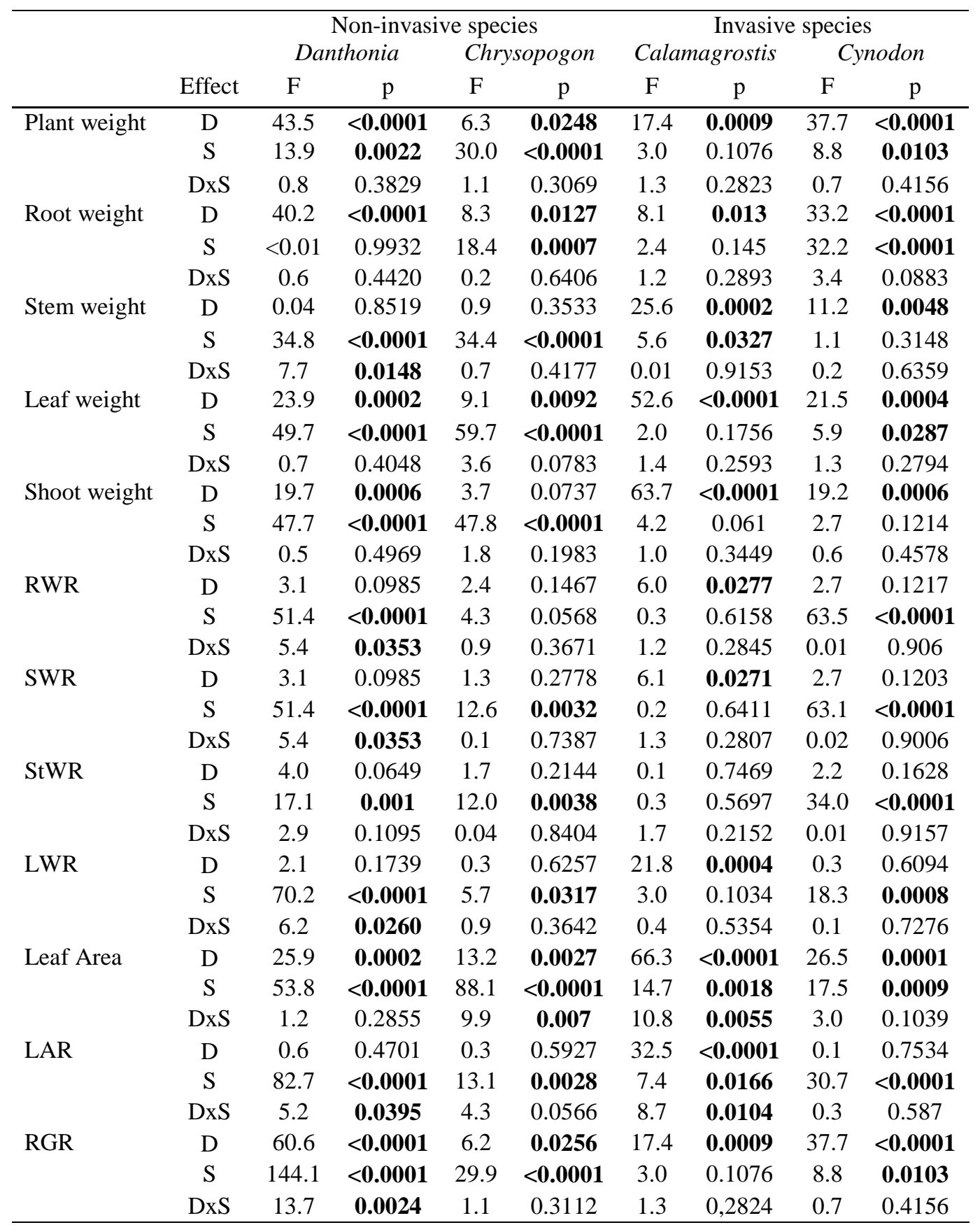

Treatment responses in biomass proportions were less conspicuous. When grown in sterilized soil - irrespective of water supply - Danthonia and Cynodon displayed higher RWR and lower StWR and LWR compared to that achieved in field soil (Table 3). For Chrysopogon StWR was lower in sterile soil than under deficit watering in field soil. Water shortage alone decreased RWR and increased StWR and LWR for Danthonia, and decreased LWR for Calamagrostis (Table 3). Compared to control, the non- 
Table 3. Biomass allocation ratios and leaf area for plants subjected to water deficit and/or soil sterilization treatments. Mean values \pm 1 SE. For each trait and species, means with the same letter in superscript are not significantly different between the two watering treatments. An asterisk indicates if the soil sterilization had significant effect for a given trait. Aadequate, $D$-deficit, further abbreviations as in Table 2.

\begin{tabular}{|c|c|c|c|c|c|c|c|c|}
\hline \multirow[b]{3}{*}{ Watering } & \multicolumn{4}{|c|}{ Non-invasive species } & \multicolumn{4}{|c|}{ Invasive species } \\
\hline & \multicolumn{2}{|c|}{ Danthonia } & \multicolumn{2}{|c|}{ Chrysopogon } & \multicolumn{2}{|c|}{ Calamagrostis } & \multicolumn{2}{|c|}{ Cynodon } \\
\hline & A & $\mathrm{D}$ & $\mathrm{A}$ & $\mathrm{D}$ & A & $\mathrm{D}$ & A & $\mathrm{D}$ \\
\hline 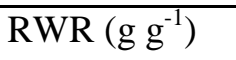 & & & & & & & & \\
\hline $\begin{array}{r}\text { Intact } \\
\text { Sterilized } \\
\text { SWR }\left(\mathrm{g} \mathrm{g}^{-1}\right)\end{array}$ & $\begin{array}{l}0.49^{\mathrm{a}} \\
0.65^{\mathrm{A}}\end{array}$ & $* \begin{array}{l}0.35^{\mathrm{b}} \\
0.67^{\mathrm{A}}\end{array}$ & $\begin{array}{l}0.56^{\mathrm{a}} \\
0.75^{\mathrm{A}}\end{array}$ & $\begin{array}{l}0.53^{\mathrm{a}} \\
0.6^{\mathrm{A}}\end{array}$ & $\begin{array}{l}0.65^{\mathrm{a}} \\
0.62^{\mathrm{A}}\end{array}$ & $\begin{array}{l}0.67^{\mathrm{a}} \\
0.69^{\mathrm{B}}\end{array}$ & $\begin{array}{l}0.43^{\mathrm{a}} \\
0.67^{\mathrm{A}}\end{array}$ & $\begin{array}{ll}* & 0.38^{\mathrm{a}} \\
& 0.61^{\mathrm{A}}\end{array}$ \\
\hline $\begin{array}{r}\text { Intact } \\
\text { Sterilized } \\
\text { StWR }\left(\mathrm{g} \mathrm{g}^{-1}\right)\end{array}$ & $\begin{array}{l}0.51^{\mathrm{a}} \\
0.35^{\mathrm{A}}\end{array}$ & $* \begin{array}{l}0.65^{\mathrm{b}} \\
0.33^{\mathrm{A}}\end{array}$ & $\begin{array}{l}* \quad 0.44^{\mathrm{a}} \\
0.25^{\mathrm{A}}\end{array}$ & & & $\begin{array}{l}0.33^{\mathrm{a}} \\
0.31^{\mathrm{B}}\end{array}$ & $\begin{array}{ll}* & 0.57^{\mathrm{a}} \\
0.34^{\mathrm{A}}\end{array}$ & $\begin{array}{l}* \quad 0.62^{\mathrm{a}} \\
0.39^{\mathrm{A}}\end{array}$ \\
\hline $\begin{array}{r}\text { Intact } \\
\text { Sterilized } \\
\text { LWR }\left(\mathrm{g} \mathrm{g}^{-1}\right)\end{array}$ & $\begin{array}{l}0.11^{\mathrm{a}} \\
0.08^{\mathrm{A}}\end{array}$ & $\begin{array}{l}0.16^{\mathrm{b}} \\
0.08^{\mathrm{A}}\end{array}$ & $\begin{array}{l}0.20^{\mathrm{a}} \\
0.09^{\mathrm{A}}\end{array}$ & * $\begin{array}{l}0.25^{\mathrm{a}} \\
0.13^{\mathrm{A}}\end{array}$ & $\begin{array}{c}0.09^{\mathrm{a}} \\
0.1^{\mathrm{A}}\end{array}$ & $\begin{array}{l}0.10^{\mathrm{a}} \\
0.08^{\mathrm{A}}\end{array}$ & $\begin{array}{c}* 0.4^{\mathrm{a}} \\
0.25^{\mathrm{A}}\end{array}$ & $\begin{array}{l}0.44^{\mathrm{a}} \\
0.28^{\mathrm{A}}\end{array}$ \\
\hline$\underset{\text { Sterilized }}{\text { Intact }} *$ & $\begin{array}{c}0.4^{\mathrm{a}} \\
0.27^{\mathrm{A}}\end{array}$ & $* \begin{array}{l}0.48^{\mathrm{b}} \\
0.25^{\mathrm{A}}\end{array}$ & $\begin{array}{l}0.24^{\mathrm{a}} \\
0.16^{\mathrm{A}}\end{array}$ & $\begin{array}{l}0.23^{\mathrm{a}} \\
0.19^{\mathrm{A}}\end{array}$ & $\begin{array}{l}0.26^{\mathrm{a}} \\
0.29^{\mathrm{A}}\end{array}$ & $\begin{array}{l}0.23^{\mathrm{b}} \\
0.24^{\mathrm{B}}\end{array}$ & $\begin{array}{l}0.18^{\mathrm{a}} \\
0.09^{\mathrm{A}}\end{array}$ & $\begin{array}{l}0.18^{\mathrm{a}} \\
0.11^{\mathrm{A}}\end{array}$ \\
\hline $\begin{array}{c}\text { Leaf area }\left(\mathrm{m}^{2}\right) \\
\text { Intact } \\
\text { Sterilized }\end{array}$ & $\begin{array}{l}0.032^{\mathrm{a}} \\
0.014^{\mathrm{A}}\end{array}$ & $* \begin{array}{l}0.019^{\mathrm{b}} \\
0.006^{\mathrm{B}}\end{array}$ & $* \begin{array}{l}0.042^{\mathrm{a}} \\
0.007^{\mathrm{A}}\end{array}$ & $* \begin{array}{l}0.023^{\mathrm{b}} \\
0.006^{\mathrm{A}}\end{array}$ & $* \begin{array}{l}0.059^{\mathrm{a}} \\
0.038^{\mathrm{A}}\end{array}$ & $\begin{array}{l}0.025^{\mathrm{b}} \\
0.024^{\mathrm{B}}\end{array}$ & $* \begin{array}{l}0.042^{\mathrm{a}} \\
0.024^{\mathrm{A}}\end{array}$ & $\begin{array}{l}0.021^{\mathrm{b}} \\
0.013^{\mathrm{A}}\end{array}$ \\
\hline $\begin{array}{r}\text { LAR }\left(\mathrm{m}^{2} \mathrm{~kg}^{-1}\right) \\
\text { Intact } \\
\text { Sterilized }\end{array}$ & $\begin{array}{l}7.96^{\mathrm{a}} \\
4.99^{\mathrm{A}}\end{array}$ & $\begin{array}{l}* 9.27^{\mathrm{a}} \\
4.33^{\mathrm{A}}\end{array}$ & $\begin{array}{l}6.91^{\mathrm{a}} \\
3.19^{\mathrm{A}}\end{array}$ & $\begin{array}{l}5.91^{\mathrm{a}} \\
4.9^{\mathrm{A}}\end{array}$ & $\begin{array}{l}7.32^{\mathrm{a}} \\
6.08^{\mathrm{A}}\end{array}$ & $\begin{array}{l}5.42^{\mathrm{b}} \\
5.48^{\mathrm{A}}\end{array}$ & $\begin{array}{l}* 6.73^{\mathrm{a}} \\
2.75^{\mathrm{A}}\end{array}$ & $\begin{array}{l}6.16^{\mathrm{a}} \\
2.9^{\mathrm{A}}\end{array}$ \\
\hline $\begin{array}{c}\mathrm{RGR}\left(\mathrm{g} \mathrm{g}^{-1} \text { day }\right. \\
\text { Intact } \\
\text { Sterilized }\end{array}$ & $\begin{array}{l}-1) \\
2.48^{\mathrm{a}} \\
0.81^{\mathrm{A}}\end{array}$ & $\begin{array}{l}1.26^{\mathrm{b}} \\
0.37^{\mathrm{B}}\end{array}$ & $\begin{array}{l}2.45^{\mathrm{a}} \\
0.86^{\mathrm{A}}\end{array}$ & $\begin{array}{l}1.59^{\mathrm{b}} \\
0.51^{\mathrm{A}}\end{array}$ & $\begin{array}{l}5.26^{\mathrm{a}} \\
4.12^{\mathrm{A}}\end{array}$ & $\begin{array}{l}3.13^{\mathrm{b}} \\
2.88^{\mathrm{A}}\end{array}$ & $\begin{array}{l}3.11^{\mathrm{a}} \\
4.17^{\mathrm{A}}\end{array}$ & $\begin{array}{l}1.62^{\mathrm{b}} \\
2.22^{\mathrm{B}}\end{array}$ \\
\hline
\end{tabular}

invasive Danthonia and Chrysopogon underwent more marked reduction in total plant foliage area than the two invasive species (56-83\% versus 36-43\%) when grown in sterile soil, and this was most marked when both soil sterilization and deficit irrigation were applied (although for Chrysopogon soil sterilization alone was sufficient to elicit the strongest response, Table 3). For the invasive Calamagrostis and Cynodon total leaf area was similar in deficit watering treatments irrespective of soil microbial status (intact or sterilized), while for the non-invasive Danthonia and Chrysopogon total leaf area declined due to soil sterilization (Table 3). Soil sterilization resulted in lower LAR for Danthonia and Cynodon, but only under adequate water supply for Calamagrostis and Chrysopogon. For Calamagrostis, deficit irrigation in itself resulted in a LAR decline similar to that achieved in sterilized soil (Table 3).

\section{Photosynthetic activity and water status}

Moderate treatment responses were observed in instantaneous photosynthetic activity (Table 4). A decline of $17-26 \%$ in $\mathrm{P}_{\mathrm{n}}$ and of $43-44 \%$ in $\mathrm{g}_{\mathrm{s}}$ appeared for Danthonia under deficit watering in both intact and sterilized soil, which resulted in a 33\% improvement of PWUE in intact soil (Table 5). Actual photochemical efficiency of PSII (ФPSII) and 
Table 4. Results of two-way ANOVA of plant physiological data. Effects are deficit watering $(D)$, soil sterilization $(S)$ and their interaction $(D x S)$. Significant $(p<0.05)$ effects are indicated in bold typeface. Abbreviations: $P_{n}-$ net photosynthetic rate, $g_{s}-$ stomatal conductance for water vapor, PWUE - instantaneous photosynthetic water use efficiency, $F_{v} / F_{m}$ - maximum photochemical efficiency of PSII, $F_{v}{ }^{\prime} / F_{m}{ }^{\prime}-$ efficiency of PSII antennae, $\Phi P S I I$ - actual photochemical efficiency of PSII, qP - photochemical quenching, NPQ non-photochemical quenching, $R W C$ - relative water content.

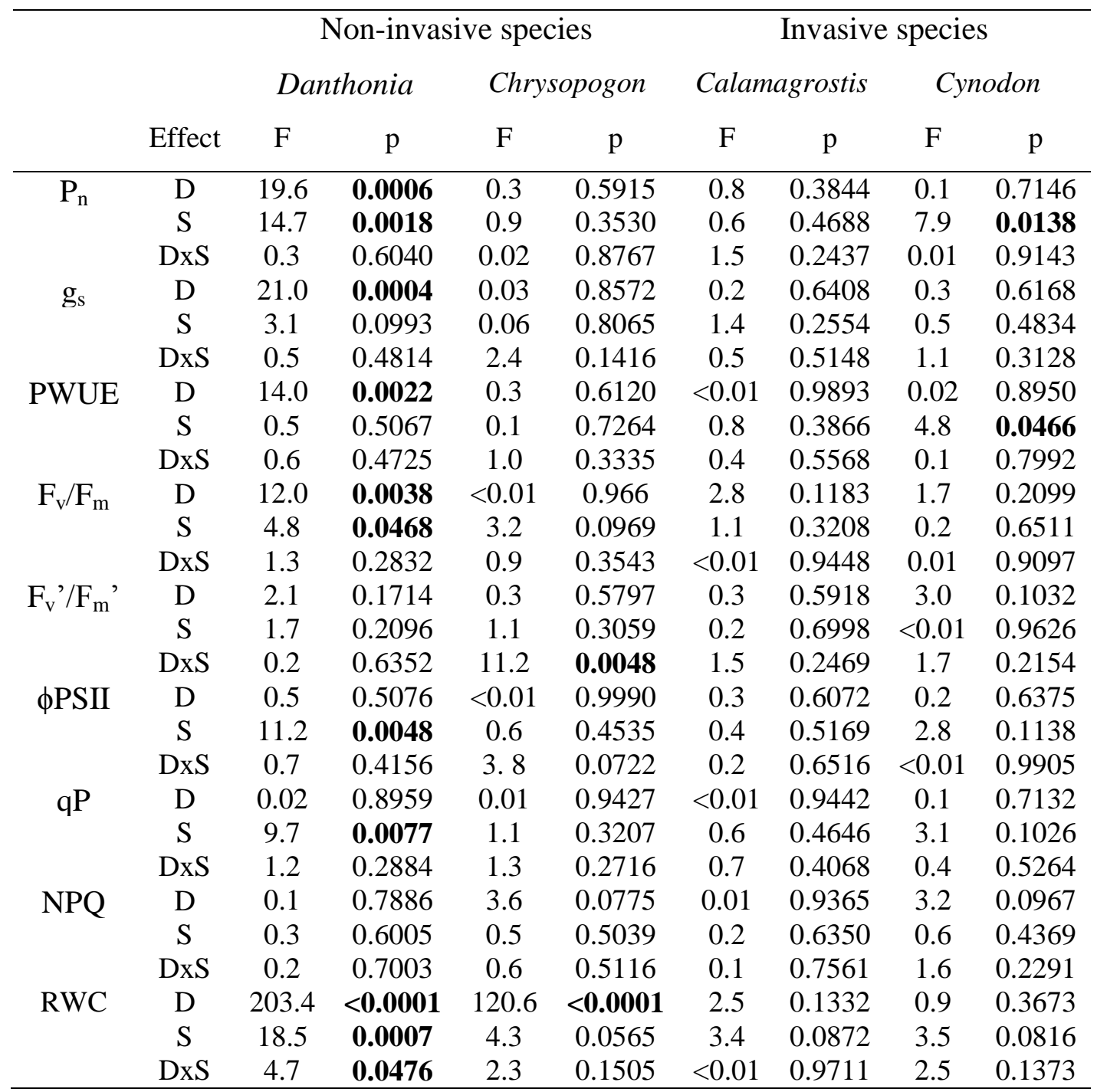

photochemical quenching (qP) declined for Danthonia in the soil sterilization treatment, while for Chrysopogon PSII antenna efficiency $\left(\mathrm{F}_{\mathrm{v}}{ }^{\prime} / \mathrm{F}_{\mathrm{m}}\right.$ ') reduced in response to soil sterilization or water deficit treatment alone. No treatment effect on leaf gas exchange and photochemistry appeared for either of the two invasive species (Table 5). Water shortage decreased leaf relative water content to a greater degree in sterilized than in intact soil for Danthonia and Chrysopogon, while caused no significant change under both watering treatments for Calamagrostis and Cynodon (Table 5). 
Table 5. Physiological traits for plants subjected to water deficit and/or soil sterilization treatments. Mean values \pm 1 SE. For each trait and species, averages with the same letter in superscript are not significantly different between the two watering treatments. An asterisk indicates if the soil sterilization had significant effect for a given trait. A-adequate, Ddeficit, further abbreviations as in Table 4.

\begin{tabular}{|c|c|c|c|c|c|c|c|c|}
\hline \multirow[b]{3}{*}{ Watering } & \multicolumn{4}{|c|}{ Non-invasive species } & \multicolumn{4}{|c|}{ Invasive species } \\
\hline & \multicolumn{2}{|c|}{ Danthonia } & \multicolumn{2}{|c|}{ Chrysopogon } & \multicolumn{2}{|c|}{ Calamagrostis } & \multicolumn{2}{|c|}{ Cynodon } \\
\hline & A & $\mathrm{D}$ & $\mathrm{A}$ & $\mathrm{D}$ & A & $\mathrm{D}$ & A & $\mathrm{D}$ \\
\hline \multicolumn{9}{|c|}{$\overline{\mathrm{P}_{\mathrm{n}}\left(\mu \mathrm{mol} \mathrm{CO} \mathrm{CO}_{2} \mathrm{~m}^{-1}\right)}$} \\
\hline Intact & $15.5^{\mathrm{a}}$ & $12.8^{\mathrm{b}}$ & $13.7^{\mathrm{a}}$ & $14.5^{\mathrm{a}}$ & $7.4^{\mathrm{a}}$ & $7.7^{\mathrm{a}}$ & $17.8^{\mathrm{a}}$ & $18.2^{\mathrm{a}}$ \\
\hline Sterilized & $13.2^{\mathrm{A}}$ & $9.8^{\mathrm{B}}$ & $11.3^{\mathrm{A}}$ & $12.8^{\mathrm{A}}$ & $7.8^{\mathrm{A}}$ & $5.7^{\mathrm{A}}$ & $12.8^{\mathrm{A}}$ & $13.7^{\mathrm{A}}$ \\
\hline \multicolumn{9}{|c|}{$\mathrm{g}_{\mathrm{s}}\left(\mathrm{mol} \mathrm{H} \mathrm{O} \mathrm{m}^{-2} \mathrm{~s}^{-1}\right)$} \\
\hline Intact & $0.29^{\mathrm{a}}$ & $0.16^{\mathrm{b}}$ & $0.09^{\mathrm{a}}$ & $0.05^{\mathrm{a}}$ & $0.14^{\mathrm{a}}$ & $0.14^{\mathrm{a}}$ & $0.10^{\mathrm{a}}$ & $0.07^{\mathrm{a}}$ \\
\hline Sterilized & $0.23^{\mathrm{A}}$ & $0.13^{\mathrm{B}}$ & $0.05^{\mathrm{A}}$ & $0.08^{\mathrm{A}}$ & $0.12^{\mathrm{A}}$ & $0.10^{\mathrm{A}}$ & $0.09^{\mathrm{A}}$ & $0.10^{\mathrm{A}}$ \\
\hline \multicolumn{9}{|c|}{ PWUE (mmol CO$\left.{ }_{2} \mathrm{~mol}^{-1} \mathrm{H}_{2} \mathrm{O}\right)$} \\
\hline Intact & $0.06^{\mathrm{a}}$ & $0.08^{\mathrm{b}}$ & $0.21^{\mathrm{a}}$ & $0.30^{\mathrm{a}}$ & $0.06^{\mathrm{a}}$ & $0.06^{\mathrm{a}}$ & $0.25^{\mathrm{a}}$ & $0.27^{\mathrm{a}}$ \\
\hline Sterilized & $0.06^{\mathrm{A}}$ & $0.08^{\mathrm{A}}$ & $0.29^{\mathrm{A}}$ & $0.26^{\mathrm{A}}$ & $0.07^{\mathrm{A}}$ & $0.06^{\mathrm{A}}$ & $0.15^{\mathrm{A}}$ & $0.15^{\mathrm{A}}$ \\
\hline \multicolumn{9}{|l|}{$\mathrm{F}_{\mathrm{v}} / \mathrm{F}_{\mathrm{m}}$} \\
\hline Intact & $0.85^{\mathrm{a}}$ & $0.81^{\mathrm{a}}$ & $0.83^{\mathrm{a}}$ & $0.81^{\mathrm{a}}$ & $0.82^{\mathrm{a}}$ & $0.79^{\mathrm{a}}$ & $0.79^{\mathrm{a}}$ & $0.81^{\mathrm{a}}$ \\
\hline Sterilized & $0.83^{\mathrm{A}}$ & $0.76^{\mathrm{B}}$ & $0.77^{\mathrm{A}}$ & $0.79^{\mathrm{A}}$ & $0.80^{\mathrm{A}}$ & $0.77^{\mathrm{A}}$ & $0.79^{\mathrm{A}}$ & $0.80^{\mathrm{A}}$ \\
\hline \multicolumn{9}{|l|}{$\mathrm{F}_{\mathrm{v}}{ }^{\prime} / \mathrm{F}_{\mathrm{m}}{ }^{\prime}$} \\
\hline Intact & $0.56^{\mathrm{a}}$ & $0.54^{\mathrm{a}}$ & $0.49^{\mathrm{a}}$ & $0.43^{\mathrm{b}}$ & $0.44^{\mathrm{a}}$ & $0.46^{\mathrm{a}}$ & $0.46^{\mathrm{a}}$ & $0.47^{\mathrm{a}}$ \\
\hline Sterilized & $0.54^{\mathrm{A}}$ & $0.50^{\mathrm{A}}$ & $0.43^{\mathrm{A}}$ & $0.47^{\mathrm{A}}$ & $0.47^{\mathrm{A}}$ & $0.52^{\mathrm{A}}$ & $0.44^{\mathrm{A}}$ & $0.49^{\mathrm{A}}$ \\
\hline \multicolumn{9}{|l|}{$\phi$ PSII } \\
\hline Intact & $0.27^{\mathrm{a}}$ & $0.24^{\mathrm{a}}$ & $0.15^{\mathrm{a}}$ & $0.11^{\mathrm{a}}$ & $0.13^{\mathrm{a}}$ & $0.14^{\mathrm{a}}$ & $0.20^{\mathrm{a}}$ & $0.21^{\mathrm{a}}$ \\
\hline Sterilized & $0.18^{\mathrm{A}}$ & $0.18^{\mathrm{A}}$ & $0.13^{\mathrm{A}}$ & $0.17^{\mathrm{A}}$ & $0.13^{\mathrm{A}}$ & $0.13^{\mathrm{A}}$ & $0.18^{\mathrm{A}}$ & $0.18^{\mathrm{A}}$ \\
\hline \multicolumn{9}{|l|}{ qP } \\
\hline Intact & $0.48^{\mathrm{a}}$ & $0.43^{\mathrm{a}}$ & $0.31^{\mathrm{a}}$ & $0.27^{\mathrm{a}}$ & $0.29^{\mathrm{a}}$ & $0.31^{\mathrm{a}}$ & $0.43^{\mathrm{a}}$ & $0.44^{\mathrm{a}}$ \\
\hline Sterilized & $0.32^{\mathrm{A}}$ & $0.36^{\mathrm{A}}$ & $0.31^{\mathrm{A}}$ & $0.36^{\mathrm{A}}$ & $0.27^{\mathrm{A}}$ & $0.30^{\mathrm{A}}$ & $0.40^{\mathrm{A}}$ & $0.37^{\mathrm{A}}$ \\
\hline \multicolumn{9}{|l|}{ NPQ } \\
\hline Intact & $2.22^{\mathrm{a}}$ & $2.26^{\mathrm{a}}$ & $3.36^{\mathrm{a}}$ & $2.54^{\mathrm{a}}$ & $3.00^{\mathrm{a}}$ & $2.92^{\mathrm{a}}$ & $3.06^{\mathrm{a}}$ & $2.53^{\mathrm{a}}$ \\
\hline Sterilized & $2.48^{\mathrm{A}}$ & $2.30^{\mathrm{A}}$ & $2.93^{\mathrm{A}}$ & $2.54^{\mathrm{A}}$ & $3.04^{\mathrm{A}}$ & $3.16^{\mathrm{A}}$ & $2.70^{\mathrm{A}}$ & $2.61^{\mathrm{A}}$ \\
\hline \multicolumn{9}{|l|}{ RWC (\%) } \\
\hline Intact & $95.3^{\mathrm{a}}$ & $82.1^{b}$ & $98.2^{\mathrm{a}}$ & $91.9^{\mathrm{b}}$ & $96.5^{\mathrm{a}}$ & $94.2^{\mathrm{a}}$ & $99.1^{\mathrm{a}}$ & $99.2^{\mathrm{a}}$ \\
\hline Sterilized & $93.0^{\mathrm{A}}$ & $75.1^{\mathrm{B}}$ & $97.8^{\mathrm{A}}$ & $89.4^{\mathrm{B}}$ & $93.8^{\mathrm{A}}$ & $91.6^{\mathrm{A}}$ & $99.0^{\mathrm{A}}$ & $97.3^{\mathrm{A}}$ \\
\hline
\end{tabular}




\section{Discussion}

Our results support the hypothesis that invasive species do not benefit from AMF association in alleviation of the effects of water shortage, while non-invasive resident species do. Under water deficit the non-invasive Danthonia and Chrysopogon performed markedly better in almost all measures of growth (root, leaf, stem and total plant biomass, and RGR, except for root and total plant biomass of Danthonia) when grown in intact soil containing native AMF community than in sterilized field soil. In contrast, the invasive Calamagrostis and Cynodon displayed no difference in growth rate and biomass accumulation between intact and sterilized soil when subject to water deficit (except for the increase in root mass of Cynodon in sterile soil). Furthermore, when plants were grown well watered but deprived of AMF symbionts, both Danthonia and Chrysopogon achieved weaker growth than in AMF containing soil at adequate watering, while neither Calamagrostis nor Cynodon displayed any reduction (root weight even increased for Cynodon). These results indicate that these two native grass species are strongly dependent on their AMF symbionts, which help them to overcome water deficit and reach greater biomass under non-limiting conditions. The two invasive grasses, however, do not appear to benefit from the symbiosis to such a degree, pointing to their less dependence on AMF association. This limited dependence of Calamagrostis and Cynodon on AMF might contribute to their success in habitats with frequent soil disturbance (Zólyomi and Fekete, 1994; Rebele and Lehmann, 2001). In line with our results, the alien $C$. dactylon was the single warm-season perennial species unresponsive in biomass accumulation to mycorrhizal colonization among numerous prairie grasses and forbs showing positive response to AMF (Wilson and Hartnett, 1998). Similarly, C. epigejos showed poor mycorrhizal colonization on coal mine spoil banks and moderate growth response to mycorrhizal infection in a pot experiment (Rydlová and Vosátka, 2001). Our earlier field study (Endresz et al., 2013) also suggested that the invasive Calamagrostis and Cynodon are not dependent on AMF symbionts, while the non-invasive Chrysopogon is (Danthonia was not examined then). In a semiarid steppe, Calamagrostis and Cynodon consistently displayed a lower degree of AMF colonization than resident grasses, including Chrysopogon, and the native bunchgrasses Festuca vaginata and Stipa borysthenica attained lower degree of AMF infection in stands invaded by Calamagrostis or Cynodon than in intact community (Endresz et al., 2013). Since in the same study we found Calamagrostis to have higher degree of AMF infection in nutrient poor sand grassland than in humus rich loess grassland, and others (Kovács and Szigetvári, 2002; Lingfei et al., 2005) reported intense AMF colonization for Cynodon, these two invasive species can be considered as facultative mycorrhizal plants.

Vogelsang et al., (2004) and Vogelsang and Bever (2009) experimentally showed a decreased dependence on AMF association for naturalized alien than for native species mostly from the Asteraceae and Poaceae families in the southern Californian flora. In another study, native and exotic species from a nutrient poor sage scrub ecosystem were compared in a nitrogen addition experiment, and native species displayed weaker growth on sterilized than on unsterilized soil, while for exotic species the presence or absence of soil microbiota did not make any difference (Bozzolo and Lipson, 2013). Weaker dependence of invasive species on beneficial soil microbes can be an inherent trait of the plant or may be the result of fast evolution after introduction in the new habitat. Seifert et al., (2009) showed a rapid evolution of reduced mycorrhizal 
dependence during invasion for the European perennial forb Hypericum perforatum in North America.

In the experiment reported here, treatments elicited moderate changes in proportional biomass allocation. Two species - Danthonia and Cynodon - showed clear compensatory response in allocation to roots when grown without soil microbiota in sterilized soil under both adequate and deficit water supply. This is in line with the mycorrhizal dependent character of Danthonia, but is completely unexpected for Cynodon evinced to be a non-dependent facultative mycorrhizal species. Leaf area ratio declined in the absence of soil microbiota not only for the AMF dependent Danthonia and Chrysopogon, but also for the non-dependent Calamagrostis and Cynodon. Further research is needed to clarify these incongruities. Slight treatment effects appeared in photosynthetic activity and for the two non-invasive species only, where water deficit, soil sterilization or the combination of these were associated with reduced photosynthetic performance. A possible explanation for the moderate changes can be that responses in instantaneous plant performance (leaf gas exchange, chlorophyll fluorescence) were slight, but cumulative measures (biomass accumulation, leaf area) detect more sensitively subtle differences. In a similar experiment, Zhu et al. (2012) observed higher chlorophyll content and improved photochemistry for mycorrhizal than for non-mycorrhizal maize plants under water shortage.

For both invasive and non-invasive categories, the $\mathrm{C}_{3}$ and the $\mathrm{C}_{4}$ species behaved remarkably similarly in spite of their different physiology and field phenology. This suggests that photosynthetic pathway type has minor role in influencing plant dependence on AMF symbiosis, but our results obtained for two $\mathrm{C}_{3}$ and two $\mathrm{C}_{4}$ species only does not allow making generalizations. In a comparison involving a much greater number of species, Hoeksema et al. (2010) found $\mathrm{C}_{4}$ grasses to respond more positively to mycorrhizal inoculation than $\mathrm{C}_{3}$ grasses did.

In conclusion, the reduction in plant growth and assimilation in response to deficit watering was smaller on AMF containing soil than on sterilized soil for the resident non-invasive Chrysopogon and Danthonia, while no such difference was detected for the invasive Calamagrostis and Cynodon. The observed responses were more obvious from cumulated measures of plant growth than from instantaneous photosynthetic performance. Even when well-watered, resident species reached greater biomass with their AMF symbionts than without them, while invasive species showed no difference. These results emphasize the importance of soil AMF community in plant responses to water shortage for natural, but less for invasive grass species. Nevertheless, the research reported here has several inherent limitations that call for further studies. The findings of the experiment conducted in a growth room should be validated under real field conditions. The applied soil sterilization might have removed not only AMF, but other members of the soil microbiota (e.g. bacteria, other fungi), which might have influenced plant responses as well. Finally, the hypothesis should be tested on a much higher number of species. As summers are expected to become warmer and drier with climate change in this semiarid temperate region (Bartholy et al., 2007), biotic interactions with beneficial soil microorganisms will be particularly needed for the resistance of natural grasslands against the spread of invasive plants. Thus, any sort of anthropogenic disturbance that has the potential of damaging the soil microbiota should be avoided in these grasslands, and probably in other ecosystems as well. 
Acknowledgements. Support from the Hungarian Scientific Research Fund (OTKA T038028) is acknowledged.

\section{REFERENCES}

[1] Al-Karaki, G., McMichael, B., Zak, J. (2004): Field response of wheat to arbuscular mycorrhizal fungi and drought stress. - Mycorrhiza 14: 263-269.

[2] Augé, R.M. (2001): Water relations, drought and vesicular-arbuscular mycorrhizal symbiosis. - Mycorrhiza 11: 3-42.

[3] Bartholy, J., Pongrácz, R., Gelybó, G. (2007): Regional climate change expected in Hungary for 2071-2100. - Applied Ecology and Environmental Research 5: 1-17.

[4] Bozzolo, F.H., Lipson, D.A. (2013): Differential responses of native and exotic coastal sage scrub plant species to $\mathrm{N}$ additions and the soil microbial community. - Plant and Soil 371: 37-51.

[5] Brundrett, M. (1991): Mycorrhizas in natural ecosystems. - Advances in Ecological Research 21: 171-313.

[6] Doubková, P., Vlasáková, E., Sudová, R. (2013): Arbuscular mycorrhizal symbiosis alleviates drought stress imposed on Knautia arvensis plants in serpentine soil. - Plant and Soil 370: 149-161.

[7] Endresz, G., Somodi, I., Kalapos, T. (2013): Arbuscular mycorrhizal colonisation of roots of grass species differing in invasiveness. - Community Ecology 14: 67-76.

[8] Endresz, G., Zöld-Balogh, Á., Kalapos, T. (2005): Local distribution pattern of Brachypodium pinnatum (Poaceae) - Field experiments in xeric loess grassland in N. Hungary. - Phyton 45: 249-265.

[9] Evelin, H., Kapoor, R., Giri, B. (2009): Arbuscular mycorrhizal fungi in alleviation of salt stress: a review. - Annals of Botany 104: 1263-1280.

[10] Fekete, G., Virágh, K., Aszalós, R. (1998): Landscape and coenological differentiation of Brachypodium pinnatum grasslands in Hungary. - Coenoses 13: 39-53.

[11] Fekete, G., Virágh, K., Aszalós, R., Précsényi, I. (2000): Static and dynamic approaches to landscape heterogeneity in the Hungarian forest-steppe zone. - Journal of Vegetation Science 11: 375-382.

[12] Goodwin, J. (1992): The role of mycorrhizal fungi in competitive interactions among native bunchgrasses and alien weeds: A review and synthesis. - Northwest Science 66: 251-260.

[13] Grace, C., Stribley, D.P. (1991): A safer procedure for routine staining of vesicular arbuscular mycorrhizal fungi. - Mycological Research 95: 1160-1162.

[14] Hale, A., Tonsor, S.J., Kalisz, S. (2011): Testing the mutualism disruption hypothesis: physiological mechanisms for invasion of intact perennial plant communities. Ecosphere 2: art110.

[15] Házi, J., Bartha, S., Szentes, Sz., Wichmann, B., Penksza, K. (2011): Seminatural grassland management by mowing of Calamagrostis epigejos in Hungary. - Plant Biosystems 145: 699-707.

[16] Hierro, J.L., Maron, J.L., Callaway, R.M. (2005): A biogeographical approach to plant invasions: the importance of studying exotics in their introduced and native range. Journal of Ecology 93: 5-15.

[17] Hildebrandt, U., Regvar, M., Bothe, H. (2007): Arbuscular mycorrhiza and heavy metal tolerance. - Phytochemistry 68: 139-146.

[18] Hoeksema, J.D., Chaudhary, V.B., Gehring, C.A., Johnson, N.C., Karst, J., Koide, R.T., Pringle, A., Zabinski, C., Bever, J.D., Moore, J.C., Wilson, G.W.T., Klironomos, J.N., Umbanhowar, J. (2010): A meta-analysis of context-dependency in plant response to inoculation with mycorrhizal fungi. - Ecology Letters 13: 394-407. 
[19] Holm, L.G., Plucknett, D.L., Pancho, J.V., Herberger, J.P. (1977): The world's worst weeds. Distribution and biology. - University Press of Hawaii, Honolulu.

[20] Horton, J.L., Neufeld, H.S. (1998): Photosynthetic responses of Microstegium vimineum (Trin.) A. Camus, a shade-tolerant, $\mathrm{C}_{4}$ grass, to variable light environments. - Oecologia 114: 11-19.

[21] Hu, J.L., Cui, X.C., Lin, X.G., Dai, J., Chen, R.R., Wang, J.H., Wong, M.H. (2014): Arbuscular mychorrhizal fungus enhances maize (Zea mays L.) growth and organic carbon sequestration in wheat (Triticum aestivum L.) straw-amended soils. - Applied Ecology and Environmental Research 12: 637-644.

[22] Illyés, E., Bölöni, J. (2007): Slope steppes, loess steppes and forest steppe meadows in Hungary. - Budapest.

[23] Jayne, B., Quigley, M. (2013): Influence of arbuscular mycorrhiza on growth and reproductive response of plants under water deficit: a meta-analysis. - Mycorrhiza 24: 109-119.

[24] Kourtev, P., Ehrenfeld, J., Häggblom, M. (2002): Exotic plant species alter the microbial community structure and function in the soil. - Ecology 83: 3152-3166.

[25] Kovács, M.G., Szigetvári, Cs. (2002): Mycorrhizae and other root-associated fungal structures of the plants of a sandy grassland on the Great Hungarian Plain. - Phyton 42: 211-223.

[26] Kristek, S., Kristek, A., Pavlović, H. (2005): The influence of mycorrhizal fungi (Glomus $s p$.) on field pea plant survival and growth in drought caused stress conditions. - Plant, Soil and Environment 51: 385-389.

[27] Lingfei, L., Anna, Y., Zhiwei, Z. (2005): Seasonality of arbuscular mycorrhizal symbiosis and dark septate endophytes in a grassland site in southwest China. - FEMS Microbiology Ecology 54: 367-373.

[28] Lorenzo, P., Rodríguez-Echeverría, S., González, L., Freitas, H. (2010): Effect of invasive Acacia dealbata Link on soil microorganisms as determined by PCR-DGGE. Applied Soil Ecology 44: 245-251.

[29] Lövei, G. (1997): Global change through invasion. - Nature 388: 627-628.

[30] Mack, R.N., Simberloff, D., Lonsdale, W.M., Evans, H., Clout, M., Bazzaz, F.A. (2000): Biotic invasions: causes, epidemology, global consequences, and control. - Ecological Applications 10: 689-710.

[31] Maxwell, K., Johnson, G.N. (2000): Chlorophyll fluorescence - a practical guide. Journal of Experimental Botany 51: 659-668.

[32] Mihály, B., Demeter, A. (2003): Invasive alien species in Hungary. National Ecological Network Vol. 6. - Authority for Nature Conservation, Ministry of Environment and Water, Budapest.

[33] Miransari, M., Bahrami, H.A., Rejali, F., Malakouti, M.J. (2008): Using arbuscular mycorrhiza to alleviate the stress of soil compaction on wheat (Triticum aestivum L.) growth. - Soil Biology and Biochemistry 40: 1197- 1206.

[34] Moora, M., Berger, S., Davison, J., Öpik, M., Bommarco, R., Bruelheide, H., Kühn, I., Kunin, W.E., Metsis, M., Rortais, A., Vanatoa, A., Vanatoa, E., Stout, J.C., Truusa, M., Westphal, C., Zobel, M., Walther, G.-R. (2011): Alien plants associate with widespread generalist arbuscular mycorrhizal fungal taxa: evidence from a continental-scale study using massively parallel 454 sequencing. - Journal of Biogeography 38: 1305-1317.

[35] Mummey, D.L., Rillig, M.C. (2006): The invasive plant species Centaurea maculosa alters arbuscular mycorrhizal fungal communities in the field. - Plant and Soil 288: 8190.

[36] Newsham, K.K., Fitter, A.H., Watkinson, A.R. (1995): Multi-functionality and biodiversity in arbuscular mycorrhizas. - Trends in Ecology and Evolution 10: 407-411.

[37] Niu, H-b., Liu, W-x., Wan, F-h., Liu, B. (2007): An invasive aster (Ageratina adenophora) invades and dominates forest understories in China: altered soil microbial communities facilitate the invader and inhibit natives. - Plant and Soil 294: 73-85. 
[38] Pringle, A., Bever, J.D., Gardes, M., Parrent, J.L., Rillig, M.C., Klironomos, J.N. (2009): Mycorrhizal symbioses and plant invasions. - Annual Review of Ecology and Systematics 40: 699-715.

[39] Rapparini, F., Peñuelas, J. (2014): Mycorrhizal fungi to alleviate drought stress on plant growth. - In: Miransari, M. (ed.) Use of microbes for the alleviation of soil stresses, Vol. 1. Springer Science+Business Media, New York, pp 21-42.

[40] Rebele, F., Lehmann, C. (2001): Biological flora of Central Europe: Calamagrostis epigejos (L.) Roth. - Flora 196: 325-344.

[41] Richardson, D.M., Allsopp, N., D'Antonio, C.M., Milton, S.J., Rejmánek, M. (2000): Plant invasions - the role of mutualism. - Biological Review 75: 65-93.

[42] Reinhart, K.O., Callaway, R.M. (2006): Soil biota and invasive plants. - New Phytologist 170: 445-457.

[43] Rydlová, J., Vosátka, M. (2001): Associations of dominant plant species with arbuscular mycorrhizal fungi during vegetation development on coal mine spoil banks. - Folia Geobotanica 36: 85-97.

[44] Seifert, E.K., Bever, J.D., Maron, J.L. (2009): Evidence for the evolution of reduced mycorrhizal dependence during plant invasion. - Ecology 90: 1055-1062.

[45] Somodi, I., Virágh, K., Podani, J. (2008): The effect of the expansion of the clonal grass Calamagrostis epigejos on the species turnover of a semi-arid grassland. - Applied Vegetation Science 11: 187-194.

[46] Steinlein, T. (2013): Invasive alien plants and their effects on native microbial soil communities. - Progress in Botany 74: 293-319.

[47] Stinson, K.A., Campbell, S.A., Powell, J.R., Wolfe, B.E., Callaway, R.M., Thelen, G.C., Hallett, S.G., Prati, D., Klironomos, J.N. (2006): Invasive plant suppresses the growth of native tree seedlings by disrupting belowground mutualisms. - PLoS biology 4: e140.

[48] Terpó, A., Zajac, M., Zajac, A. (1999): Provisional list of Hungarian archaeophytes. Thaiszia 9: 41-47.

[49] Török, P., Matus, G., Papp, M., Tóthmérész, B. (2008): Secondary succession in overgrazed Pannonian sandy grasslands. - Preslia 80: 73-85.

[50] Trouvelot, A., Kough, J.L., Gianinazzi-Pearson, V. (1986): Mesure du taux de mycorhization VA d'un systéme radiculare. Recherche de méthodes d'estimation ayant une signification fonctionelle. - In: Mycorrhizae: physiology and genetics-Les mycorhizes: physiologie et génétique. Proceedings of the 1st ESM/1er SEM, Dijon, 1-5 July 1985.-INRA, Paris, pp. 217-221.

[51] Valéry, L., Fritz, H., Lefeuvre, J-C., Simberloff, D. (2008): In search of a real definition of the biological invasion phenomenon itself. - Biological Invasions 10: 1345-1351.

[52] Valéry, L., Fritz, H., Lefeuvre, J-C., Simberloff, D. (2009): Ecosystem-level consequences of invasions by native species as a way to investigate relationships between evenness and ecosystem function. - Biological Invasions 11: 609-617.

[53] Vitousek, P.M., D'Antonio, C.M., Loope, L.L., Rejmánek, M., Westbrooks, R. (1997) Introduced species: a significant component of human-casued global change. - New Zealand Journal of Ecology 21: 1-16.

[54] Vogelsang, K.M., Bever, J.D. (2009): Mycorrhizal densities decline in association with nonnative plants and contribute to plant invasion. - Ecology 90: 399-407.

[55] Vogelsang, K.M., Bever, J.D., Griswold, M., Schultz, P.A. (2004): The use of mycorrhizal fungi in erosion control applications. Final Report for Caltrans. Contract number 65A0070. - California Department of Transportation, Sacramento, California, USA.

[56] von Caemmerer, S., Farquhar, G.D. (1981): Some relationships between the biochemistry of photosynthesis and the gas exchange of leaves. - Planta 153: 376-384.

[57] Wang, B., Qiu, Y-L. (2006): Phylogenetic distribution and evolution of mycorrhizas in land plants. - Mycorrhiza 16: 299-363. 
[58] Wilson, G.W.T., Hartnett, D. (1998): Interspecific variation in plant responses to mycorrhizal colonization in tallgrass prairie. - American Journal of Botany 85: 17321738.

[59] Wilson, G.W., Hickman, K.R., Williamson, M.M. (2012): Invasive warm-season grasses reduce mycorrhizal root colonization and biomass production of native prairie grasses. Mycorrhiza 22: 327-336.

[60] Wu, Q-S., Xia, R-X. (2006): Arbuscular mycorrhizal fungi influence growth, osmotic adjustment and photosynthesis of citrus under well-watered and water stress conditions. Journal of Plant Physiology 163: 417-425.

[61] Zhang, Q., Yang, R., Tang. J., Yang, H., Hu, S., Chen, X. (2010): Positive feedback between mycorrhizal fungi and plants influences plant invasion success and resistance to invasion. - PLoS One 5: e12380.

[62] Zhu, X.C., Song, F.B., Liu, S.Q., Liu, T.D., Zhou, X. (2012): Arbuscular mycorrhizae improves photosynthesis and water status of Zea mays L. under drought stress. - Plant, Soil and Environment 58: 186-191.

[63] Zólyomi, B., Fekete, G. (1994): The Pannonian loess steppe: differentiation in space and time. - Abstracta Botanica 18: 29-41. 